\title{
Firm entry and institutional lock-in: an organizational ecology analysis of the global fashion design industry
}

\author{
Rik Wenting* and Koen Frenken**,†
}

\begin{abstract}
Few industries are more concentrated geographically than the global fashion design industry. We analyze the geography and evolution of the fashion design industry by looking at the yearly entry rates at the city level. In contrast to other industry studies, we find that legitimation processes operate locally and competition processes globally. This result points to the rapid turnover of ideas in the fashion design industry on the one hand and the global demand for fashion apparel on the other hand. We attribute the decline of Paris in the post-war period to "institutional lock-in," which prevented a ready-to-wear cluster to emerge despite the presence of the haute couture cluster. An extended organizational ecology model provides empirical support for this claim.
\end{abstract}

JEL classification: L10, L67, M13, R11, R12.

\section{Introduction}

Few industries are more concentrated geographically than the global fashion design industry. Most of the successful fashion designers are located in a handful of cities: Paris, London, New York, and Milan. The industry was even more concentrated before the World War II with Paris as the single center in global fashion design. It was only after 1945 that Paris lost its dominance with London, Milan, and New York emerging as new centers of fashion design.

\footnotetext{
${ }^{\star}$ Rik Wenting, Utrecht School of Economics, Utrecht University, Janskerkhof 12, 3512BL Utrecht, The Netherlands. e-mail: r.wenting@gmail.com

${ }^{*}$ Koen Frenken, School of Innovation Sciences, Eindhoven University of Technology, P.O. 513, 5600MB, Eindhoven, The Netherlands. e-mail: k.frenken@tue.nl

$\dagger$ Main author for correspondence
} 
Some have related the rather sudden shift from a mono-centered to a poly-centered geography of fashion design to the emergence of ready-to-wear (prêt-à-porter) fashion (Waddell, 2004). Parisian designers dominated haute couture but were initially reluctant to embrace the ready-to-wear segment, which became the main segment during the post-war period. Most Parisian designers considered ready-to-wear to be too commercial and a threat to the high standards of haute couture. For a while, French haute couturiers were not even allowed to practice ready-to-wear according to the guidelines of the Syndicate Chamber of Parisian Couture.

We propose to explain the geography and evolution of the ready-to-wear fashion design industry by looking at the yearly entry rates following an organizational ecology approach. The main contribution is that we provide the first organizational ecology study on a creative industry ${ }^{1}$ whereas previous contributions focused on manufacturing and service sectors (Hannan and Carroll, 1992; Hannan et al., 1995; Bigelow et al., 1997; Carroll and Hannan, 2000). In the first part of the article, we ask the question to what extent the insights from organizational ecology obtained so far are transferable to creative industries. In particular, we question the generality of the results of Hannan et al. (1995) and Bigelow et al. (1997) who found that in the car industry legitimation processes operated globally and competition processes locally. In the fashion design industry, we expect the opposite to be true due to the rapid turnover of fashion ideas on the one hand and the global demand for fashion apparel on the other hand.

In the second part of our study, we focus on the decline of Paris with the advent of the ready-to-wear segment next to the haute couture segment. We understand this historical development as a case of institutional lock-in, which prevented a new, related cluster to emerge from an existing cluster. To assess this claim empirically, we analyze the effect of the presence of haute couture designers on ready-to-wear foundings in the various cities in an extended organizational ecology framework.

We proceed as follows. We first explain in Section 2 the core model of organizational ecology and how it can be applied at different geographical scales simultaneously to assess the level at which legitimation and competition processes take place. We discuss our data in Section 3 and present the results of our analysis in Section 4.

\footnotetext{
${ }^{1}$ We consider creative industries to be industries that produce goods and services that have a high symbolic content. Production in creative industries draws heavily on symbolic knowledge and creative individuals. Following an influential report by the UK Department of Culture, Media and Sport (DCMS, 2001), the following industries are often grouped under the heading of creative industries: advertising, architecture, the art and antiques market, crafts, design, designer fashion, film and video, interactive leisure software, music, the performing arts, publishing, software and computer services, television and radio.
} 
The specific history of the Parisian cluster is discussed and analyzed in Section 5. We end with a conclusion in Section 6.

\section{Organizational ecology}

The main goal of organizational ecology studies is to understand the dynamics of populations of organizations (Hannan and Freeman, 1989; Hannan and Carroll, 1992). The ecology analogy refers to the concept of markets as niches that, once established, are filled by organizations until the carrying capacity of the niche is reached. In ecological processes, the rate of birth of new entities is density dependent. When the niche is discovered, the birth rate is positively dependent on density as each existing entity may bring forth new entities. With the niche becoming saturated, density becomes detrimental for birth due to competition for resources. Specifically, the population level will stabilize at a level depending on the carrying capacity of the niche.

The analogy in organizational foundings holds that the positive density effect reflects legitimation. Legitimation is rather loosely defined as "social taken-forgrantedness" (Hannan et al., 1995: 510) and includes all positive feedback processes that encourage entrepreneurs to start a new business in a particular niche. Aldrich and Fiol (1994) distinguish between cognitive and socio-political legitimacy. "Cognitive legitimation refers to the spread of knowledge about a new venture" (Aldrich and Fiol, 1994: 648). This knowledge is generated by incumbents and diffuses to potential entrepreneurs inducing the latter to start the same type of business (see also, Hannan et al., 1995: 512). "Socio-political legitimation refers to the process by which key stakeholders, the general public, key opinion leaders, or government officials accept a venture as appropriate and right, given existing norms and laws" (Aldrich and Fiol, 1994: 648). The negative effect of density dependence reflects market competition, which is assumed to rise non-linearly, as each new competitor entering the population has an increasing marginal effect on the level of competition.

Accordingly, and following notation of Bigelow et al. (1997), the core model of organizational ecology can be written as:

$$
\lambda(t)=\exp \left(\beta_{0}+\beta_{1} N_{t}+\beta_{2} N_{t}^{2}\right),
$$

where $\lambda(t)$ stands for the yearly organizational founding rate and $N_{t}$ for the density of the population (i.e. the number of organizations) at time $t$. The hypotheses hold that $\beta_{1}>0$ and $\beta_{2}<0$. The model is often extended with dummies referring to particular historical periods that affect the founding rates, for example, war periods or periods that are characterized by a particular dominant technology (Bigelow et al., 1997).

An interesting conceptual extension to the model, which we use in our analysis of urban clusters in the global fashion design industry, is the inclusion of different geographical levels of analysis. This allows one to analyze at which spatial levels 
legitimation and competition processes take place. ${ }^{2}$ Hannan et al. (1995) analyzed national founding rates of automobile manufacturers in five European countries and found that competition took place at national level, while legitimation processes were found to operate at the supra-national level. Similarly, looking at founding rates of automobile manufacturers in different US regions, Bigelow et al. (1997) found that competition was regional, while legitimation occurred across US regions. ${ }^{3}$

We will make use of the multi-level approach introduced by Hannan and colleagues when analyzing the founding rates of fashion houses at the urban and the global level. However, we question the generality of the results of Hannan et al. (1995) and Bigelow et al. (1997) as we expect legitimation processes to be local and competition processes to be global. The reason for the reverse hypothesis lies in the specificity of fashion design. Given the short product lifecycle (usually six months) there is a rapid turnover of ideas with the values of ideas decaying rapidly in time. Ideas typically spread through people moving between companies or setting up their own spinoff companies, and these transfer mechanisms are predominantly local (Klepper, 2007a; Wenting, 2008; Breschi and Lissoni, 2009). As a consequence, cognitive legitimation will occur primarily within design clusters rather than between them. The characteristics of fashion design are thus rather different from manufacturing where knowledge is more accumulative and to a larger extent codified in patents, standards, handbooks and machinery. Similarly, processes supporting social and political legitimation in the fashion design industry are expected to operate mostly at the local level with the prime institutions being bounded to local authorities (design schools, fashion weeks, designer associations) (Waddell, 2004).

Concerning the competition effect in organizational ecology, we also expect fashion design to be different from manufacturing as fashion designers compete globally for clients. Fashion being a luxury good and insensitive to transportation costs, the locus of consumption is not tied to the origin of production. By contrast, at least historically, manufacturing goods compete in regional markets because the transportation costs account for a large share of total costs. ${ }^{4}$

Thus, for the global fashion design industry, we specify:

$$
\lambda_{i}(t)=\exp \left(\beta_{0}+\beta_{1} n_{i t}+\beta_{2} N_{t}^{2}\right),
$$

for each city $i$ and with $n$ standing for urban density. Again, the hypotheses hold that $\beta_{1}>0$ and $\beta_{2}<0$.

\footnotetext{
${ }^{2}$ The use of nested scales need not only refer to geographical scales, but could also refer to any other type of hierarchical classification.

${ }^{3}$ For more general discussions about industrial dynamics and economic geography, see Cattani et al. (2003), Van Wissen (2004), Boschma and Frenken (2006), and Frenken and Boschma (2007).

${ }^{4}$ For services, the competition effect is expected to be even more local.
} 


\section{Data and methodology}

To test our hypotheses we collected a unique dataset on entries in the global fashion design industry. The data we collected stem from various sources, most importantly, the Thames \& Hudson Dictionary of Fashion and Fashion Designers by O'Hara Callan (1998) and Watson's (2004) 20th Century Fashion: 100 Years of Style by Decade and Designer. The data were updated till the year 2005 using the Internet sources, of which designerhistory.com is the most notable one. Our data encompasses information on 565 of the world's top designers in the haute couture and ready-to-wear industry, from the start of the industry in 1858.

From the total of 565 designers mentioned in our sources, 510 designers started their own firm. This means that 55 designers have been active as freelancers or employees, and are left out of the analysis. Designers were classified as entries in haute couture and/or ready-to-wear based on a reading of their biography. We counted 147 entrants in haute couture and 406 entrants in the ready-to-wear industry reflecting the larger size of the ready-to-wear market compared to the elitist haute couture market. The 43 designers that produced haute couture as well as ready-to-wear are included in both populations with the time of entry corresponding to the year a designer entered the respective market segment. Designers were also classified as being located in Paris, London, New York, Milan, or elsewhere. ${ }^{5}$

Figure 1 shows the total number of entries and exits in the ready-to-wear segment each year, as well as the industry's world population. Here it is clear that the industry has witnessed sustained growth throughout the whole period. ${ }^{6}$ Figure 2 shows the population in each of the four largest clusters being Paris, London, New York, and Milan. The total number of entries and exits, and the industry's world population for the haute couture segment in given in Figure 3, while Figure 4 shows the population in each of the four largest clusters. The figures show that Paris dominated the haute couture industry from its onset in 1858 up until today. Yet, Paris started relatively late in the ready-to-wear segment and did not achieve dominance over New York or London in this segment. At present, New York and London even outnumber Paris in terms of the number of ready-to-wear fashion houses.

In order to test the two hypotheses (legitimation processes operate locally and competition processes globally), we include density dependence of both types at both spatial levels. So, we let the yearly founding rates in each city depend on local density

\footnotetext{
${ }^{5}$ Here, city boundaries include suburbs and neighbouring towns.

${ }^{6}$ While in most manufacturing industries, the number of firms first rises and then falls during an industry "shakeout" (Hannan et al., 1995; Klepper and Simons, 1997), this pattern is absent in the top of fashion design. This is likely a consequence of the high number of small niches or "submarkets" (Klepper and Thompson, 2006). In fashion design, scale economies in production are of less importance compared to manufacturing activities. Indeed, fashion designers are more concerned with remaining creatively relevant and maintaining an image of exclusivity (Banks et al., 2000).
} 


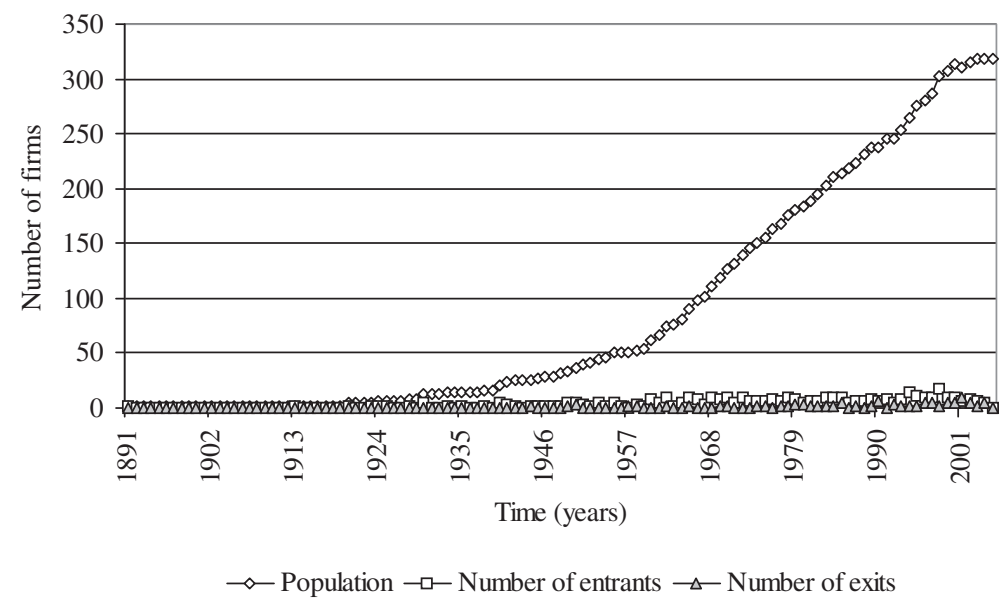

Figure 1 Ready-to-wear population, 1891-2005.

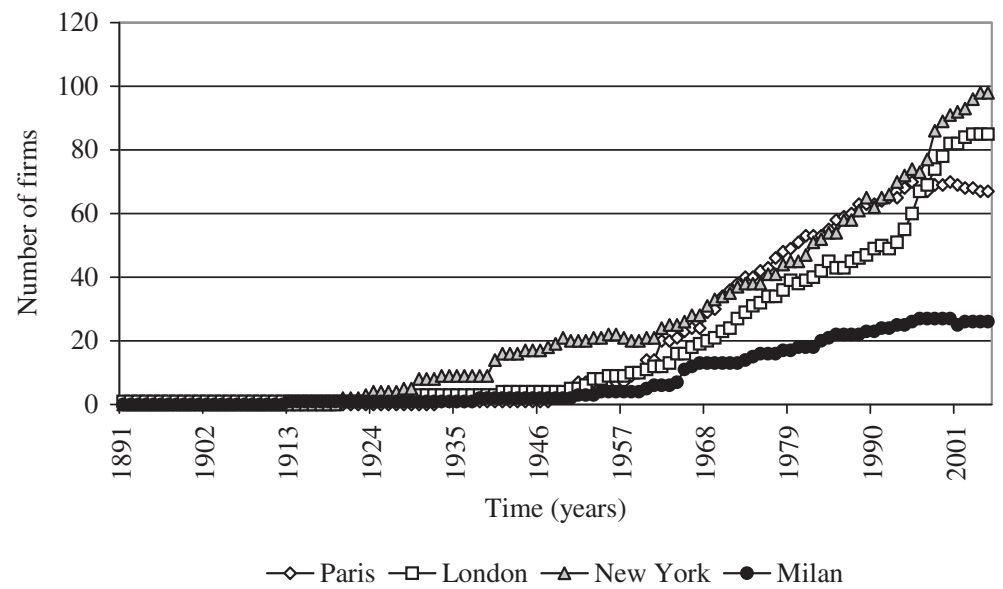

Figure 2 Ready-to-wear population by city, 1891-2005.

and local density squared and on global density and global density squared. Following Hannan et al. (1995) and Bigelow et al. (1997), we define global density as the density of fashion houses outside the city in question (also referred to as total remaining density).

We limit the analysis to ready-to-wear foundings as a distinct segment in the global fashion design industry. Restricting the analysis to the ready-to-wear segment allows us to analyze the effect of the presence of haute couture on the formation of the new ready-to-wear cluster in the second part of our study. The ready-to-wear segment started in 1891 while the data ends in 2005. Analyzing the four largest urban 


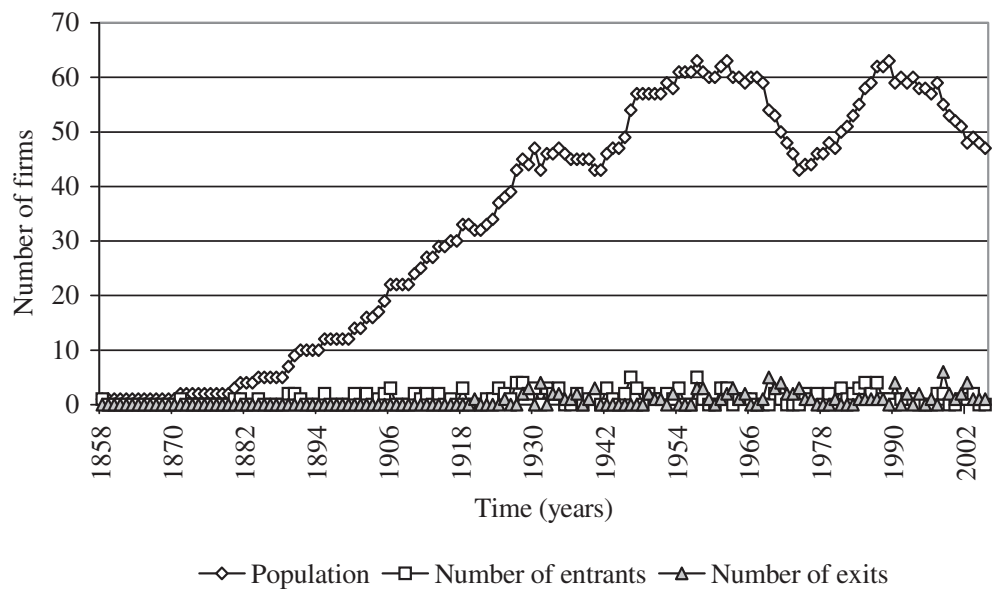

Figure 3 Haute couture population, 1858-2005.

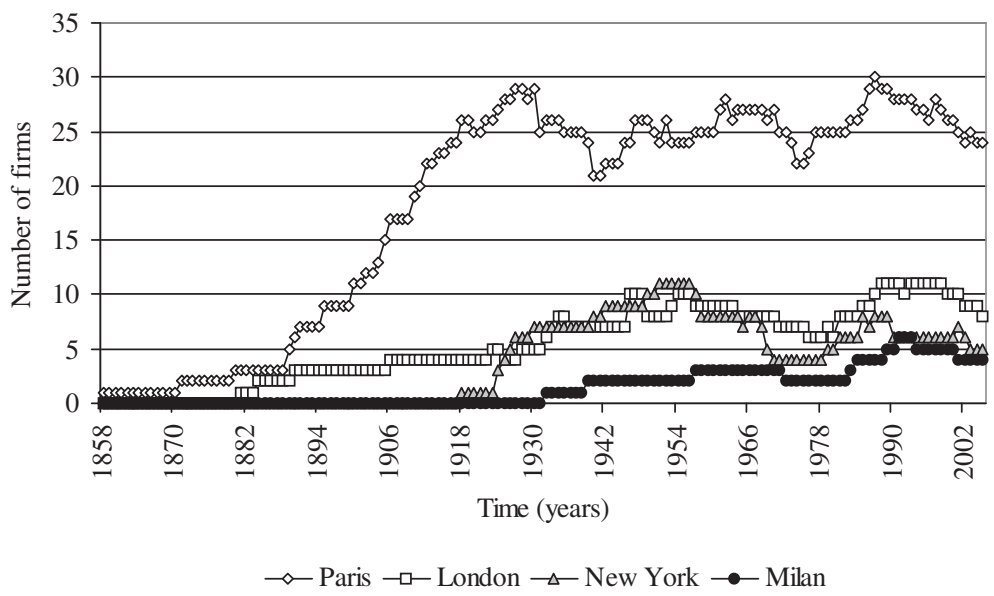

Figure 4 Haute couture population by city, 1858-2005.

clusters (Paris, London, New York, and Milan) and pooling the observations, we have a total of 460 yearly founding rates. As controls, we use dummies for the two world wars (1914-1918 and 1939-1945). We distinguish here between the United States (WW_US) and Europe (WW_EUROPE), because the two world wars have most likely disrupted the European market much more than the US market (Merlo and Polese, 2006).

Our dependent variable counts the number of yearly foundings and should therefore be dealt with as "count data." Probably the most common regression model 
applied in this respect is the Poisson regression model, which is estimated by means of maximum likelihood estimation techniques. However, due to overdispersion we resort to estimating negative binomial regression models instead, which add a parameter $\alpha$ to the model capturing unobserved heterogeneity and thus correcting for overdispersion in the data.

Apart from the problem of overdispersion, our data set also suffers from an excessive amount of zeros relative to the amount of actual observed interregional collaborations. Although the negative binomial regression model already improves upon the under-prediction of zeros, Vuong tests indicate that we should use a zero-inflated variant of the negative binomial regression model. The zero-inflated negative binomial model considers the existence of two (latent) groups within the population: a group having strictly zero counts and a group having a non-zero probability of counts different than zero. Correspondingly, its estimation process consists of two parts. The first part contains a logit regression of the predictor variables on the probability that there is no founding at all. The second part contains a negative binomial regression on the probability of each count for the group that has a non-zero probability of count different than zero. Since we are interested in the rate of foundings and only use the zero inflated model to correct for the excessive number of zero counts, we only report the negative binomial part of our analyses. Results for the zero inflated part can be found in Table A1 in Appendix A. ${ }^{7}$

\section{Results}

Table 1 shows the results of our analysis. Model 1 reports on the results assuming local legitimation and local competition. Both estimates are significant and of the expected sign with density having a positive effect on foundings and density squared a negative effect on foundings. Yet, when we introduce global legitimation and global competition in Model 2, we observe that local competition is no longer significant while global competition is significant (at the 10 percent level). This result supports our two main hypotheses that the geographical structure of the fashion design industry is such that designers are induced to set up their own business through local interaction processes, while they compete for customers at a global scale. Local legitimation processes promote further entry within each cluster, while global competition ultimately limits the growth of the industry as a whole.

The finding is important because it shows the specificity of the fashion design industry and its fundamental difference with the automobile industry, for which the

\footnotetext{
${ }^{7}$ Signs in the zero-inflated part need to be interpreted in reverse manner compared to the negative binomial part of the zero-inflated model as reported in the main text in Tables 1 and 2. The results in Appendix Table A1 show that fewer coefficients are significant compared to the negative binomial part reported in Tables 1 and 2. The significant coefficients in the zero-inflated part are consistent with the results of the negative binomial part of the zero-inflated model reported in Tables 1 and 2.
} 
Table 1 Estimates of the zero-inflated binomial regression analyses (dependent variable: yearly founding rate in ready-to-wear)

\begin{tabular}{|c|c|c|}
\hline & Model 1 & Model 2 \\
\hline$n$ & 0.042 & 0.040 \\
\hline Stand. error & $(0.011)$ & $(0.013)$ \\
\hline$P$-value & 0.000 & 0.003 \\
\hline$n^{2}$ & -0.0003 & -0.0002 \\
\hline Stand. error & $(0.0001)$ & $(0.0001)$ \\
\hline$P$-value & 0.018 & 0.164 \\
\hline N & & 0.005 \\
\hline Stand. error & & $(0.006)$ \\
\hline$P$-value & & 0.390 \\
\hline$N^{2}$ & & -0.00003 \\
\hline Stand. error & & $(0.00002)$ \\
\hline$P$-value & & 0.096 \\
\hline WW_US & 2.465 & 2.932 \\
\hline Stand. error & $(2.344)$ & $(2.328)$ \\
\hline$P$-value & 0.293 & 0.208 \\
\hline WW_EUROPE & -1.349 & -1.642 \\
\hline Stand. error & $(2.260)$ & $(2.289)$ \\
\hline$P$-value & 0.551 & 0.473 \\
\hline Constant & -0.745 & -0.788 \\
\hline Stand. error & $(0.222)$ & $(0.286)$ \\
\hline$P$-value & 0.001 & 0.006 \\
\hline Log likelihood & -418.206 & -405.516 \\
\hline $\operatorname{LR} x^{2}$ & 45.91 & 61.65 \\
\hline Number of observations & 460 & 460 \\
\hline Number of non-zero observations & 175 & 175 \\
\hline
\end{tabular}

opposite results were found (Hannan et al., 1995; Bigelow et al., 1997). The results also suggest that local legitimation processes are indeed important, and drive, at least partially, the high degree of clustering of the industry in just four "global cities," and the persistence of this clustering over time.

\section{Institutional lock-in?}

Few industries have seen such a stable geography as fashion design with the main clusters of today being the same as a century ago. Yet, an important shift has taken place during the last century with Paris losing its dominance. The share of 
Paris-based firms started to fall rapidly from $~ 70 \%$ up until 1923 , to $36 \%$ in 1941 . Currently $<25 \%$ of the top fashion houses in the world are located in Paris. At the same time, London, New York, and Milan increased their share of designers with both New York and London currently outnumbering Paris.

Some have attributed the marked shift in spatial concentration of the industry to the rapid growth of the ready-to-wear market in the 1950s and 1960s as a new segment next to haute couture (Waddell, 2004). The term ready-to-wear describes a method of buying clothes whereby the customer no longer has to have clothes made to measure. As such, ready-to-wear is a simplified form of high fashion and demands less artistic skill from the designer. Yet, it also involves complicated sizing problems and manufacture in large quantities as well as professional marketing.

Initially, Parisian haute couturiers were not allowed to practice ready-to-wear according to the guidelines of the Syndicate Chamber of Parisian Couture (Chambre Syndicale de la Couture Parisienne) founded in 1911 (Waddell, 2004). ${ }^{8}$ This association regulated the profession of the French haute couturiers. As a consequence French couturiers entered the ready-to-wear market much later than designers outside Paris. It took until 1973 for a separate entity to be established in Paris setting guidelines for ready-to-wear, while similar institutions were set up much earlier in London (in 1947), Milan (in 1958), and New York (in 1962). The attempts by the Syndicate can be understood as a case of institutional lock-in (Grabher, 1993; Hassink, 2005), where firms with vested interest in haute couture try to raise entry barriers for a new, less exclusive, line of business as to protect the cultural meaning and exclusivity of (Parisian) haute couture fashion.

The strategy of the Syndicate was, however, just one manifestation of a more general resistance within Paris against "commercialization" and "popularization" of fashion design. Parisian designers traditionally design for the rich-and-famous elite and continued to do so after the emergence of ready-to-wear. As such, the location of a fashion house plays a role in establishing a particular type of brand (Jansson and Power, 2010). Paris-based houses signal exclusivity: the (Parisian) concept of haute couture holds that fashion is, and should be, artistic, exclusive and tailor-made. By contrast, London, Milan, and New York saw a democratization of design consumption with youngsters expressing themselves in ready-to-wear fashion and entrepreneurs quickly reacting to this growing demand for fashion (Waddell, 2004). The continued institutional differentiation between haute couture and other forms of fashion is evident from the continued protected status of haute couture under French law. Only couture houses that have been granted the haute couture label are allowed to use the specification. Up until today, a special committee residing

\footnotetext{
${ }^{8}$ The Chambre Syndicale de la Couture Parisienne was previously known as Chambre Syndicale de la Couture Francaise, founded in 1868.
} 
under the French Ministry of Industry is reviewing haute couture houses each year. ${ }^{9}$

To analyze the particular history of the Parisian fashion design cluster, we can relate the yearly entry rates into the ready-to-wear market to the presence of a local cluster in haute couture. One can expect the emergence and growth of the ready-to-wear segment in each cluster to be related to the presence of haute couture designers. Generally, the development of new industries profits from the presence of related industries (Klepper, 2002). The argument holds that knowledge and practices can be easily transplanted from the related industry to the emerging industry within the same cluster. ${ }^{10}$

In an organizational ecology framework, the effect of haute couture designers on the development of ready-to-wear segment can be introduced by extending the model with the density of haute couture designers. The effect of haute couture density on foundings in the ready-to-wear segment is expected to be positive. Each haute couture designer could decide to enter the more profitable line of business in the ready-to-wear segment. Indeed, quite a number of designers decided to do so: $29 \%$ of all design houses in haute couture diversified out into ready-to-wear at some stage of their existence. A second mechanism through which the presence of a related industry can fuel the growth of a new cluster is through entry by spinoff (Klepper, 2002). Indeed, 97 out of 406 ready-to-wear entries (24\%) were spinoffs from haute couture firms, in the sense that the founder of the ready-to-wear firm previously worked as an assistant in an haute couture firm.

To test whether local haute couture density fuelled entry in the new segment, we extend the specification in Equation (2), and get:

$$
\lambda_{i}(t)=\exp \left(\beta_{0}+\beta_{1} n_{i t}+\beta_{2} N_{t}^{2}+\beta_{3} m_{i t}\right),
$$

where $m_{i t}$ stands for the yearly density in haute couture in city $i$. The hypotheses hold that $\beta_{1}>0, \beta_{2}<0$ and $\beta_{3}>0$.

The model specification in Equation (3), however, neglects the noted institutional differences between the fashion clusters. Due to the institutional and cultural resistance among Parisian haute couture designers regarding ready-to-wear, as explained before, entry rates in Paris are expected to be structurally lower than elsewhere. To address the specificity of the Parisian context, we introduce a dummy variable for Paris. The hypothesis holds that its sign is negative reflecting the "institutional lock-in" within the Parisian haute couture community.

\footnotetext{
${ }^{9} \mathrm{http} / / /$ www.modeaparis.com/va/index.html.

${ }^{10}$ Examples include the emergence of the car industry out of the bicycles and engine industries (Klepper, 2002; Cantner et al., 2006; Boschma and Wenting, 2007), the emergence of the film industry out of theatres (Mezias and Kuperman, 2001), the emergence of the television industry from the radio industry (Klepper, 2007b), and the emergence of the tire industry from the rubber goods industry (Buenstorf and Klepper, 2009).
} 
Table 2 Estimates of the zero-inflated binomial regression analyses (dependent variable: yearly founding rate in ready-to-wear)

\begin{tabular}{|c|c|c|}
\hline & Model 3 & Model 4 \\
\hline$n$ & 0.043 & 0.031 \\
\hline Stand. error & $(0.014)$ & $(0.015)$ \\
\hline$P$-value & 0.002 & 0.046 \\
\hline$n^{2}$ & -0.0002 & -0.0001 \\
\hline Stand. error & $(0.0001)$ & $(0.0001)$ \\
\hline$P$-value & 0.127 & 0.454 \\
\hline N & 0.003 & 0.007 \\
\hline Stand. error & $(0.006)$ & $(0.006)$ \\
\hline$P$-value & 0.557 & 0.275 \\
\hline$N^{2}$ & -0.00003 & -0.00004 \\
\hline Stand. error & $(0.00002)$ & $(0.00002)$ \\
\hline$P$-value & 0.150 & 0.055 \\
\hline$m$ & -0.005 & 0.063 \\
\hline Stand. error & $(0.007)$ & $(0.030)$ \\
\hline$P$-value & 0.536 & 0.036 \\
\hline PARIS & & -1.359 \\
\hline Stand. error & & $(0.579)$ \\
\hline$P$-value & & 0.019 \\
\hline WW_US & 2.916 & 2.577 \\
\hline Stand. error & $(2.469)$ & $(2.244)$ \\
\hline$P$-value & 0.238 & 0.251 \\
\hline WW_EUROPE & -1.709 & -1.476 \\
\hline Stand. error & $(2.442)$ & $(2.214)$ \\
\hline$P$-value & 0.484 & 0.505 \\
\hline Constant & -0.694 & -1.008 \\
\hline Stand. error & $(0.303)$ & $(0.359)$ \\
\hline$P$-value & 0.022 & 0.005 \\
\hline Log likelihood & -405.223 & -401.232 \\
\hline $\operatorname{LR} \chi^{2}$ & 61.82 & 66.04 \\
\hline Number of observations & 460 & 460 \\
\hline Number of non-zero observations & 175 & 175 \\
\hline
\end{tabular}

In Table 2 we tested the extended organizational ecology model in Model $3 .^{11}$ Surprisingly, the local density of haute couture designers did not fuel the cluster of ready-to-wear with new entrants as the coefficient is insignificant. The absence of any

\footnotetext{
${ }^{11}$ We do not include the square of haute couture density, because the two separate market segments do not compete for the same clientele.
} 
positive effect of haute couture designers on foundings in ready-to-wear may, however, may be caused by the specific Parisian context, where the strong presence of haute couture possibly had a negative effect on the formation of the ready-to-wear cluster due to its unionized structure.

Model 4 replicates Model 3 but now including a PARIS dummy. This dummy is significant and of the expected negative sign. At the same time, the local density of haute couture designers turns significant and positive in Model 4. These results indicate two important phenomena. First, Paris indeed shows a structurally lower founding rate compared to the other three clusters suggesting a specific local (institutional) context which was less conducive for entrepreneurs to start a business in the ready-to-wear segment. Second, our previous hypothesis that haute couture density facilitated the formation of the ready-to-wear clusters is now supported with the coefficient being positive and significant. ${ }^{12}$ It is only after controlling for the local specificity of the Paris cluster that the expected positive effect of haute couture density can be observed. ${ }^{13}$ Finally, to test for robustness, we compared these results to a standard negative binomial model. As reported in Table A2 Appendix A, the main results are robust. ${ }^{14}$

\section{Concluding remarks}

Having provided the first organizational ecology study on a "creative industry," we showed that the geography and industrial evolution of the fashion design industry is

\footnotetext{
${ }^{12}$ Running the regressions separately for entries by spinoff firms and for entries by non-spinoff firms we found that the results for non-spinoff firms are the same as the results for all firms in terms of sign and significance of coefficients. Interestingly, the results for spinoff firms are different from the results for all firms. In particular, in Model 3, the local density of haute couture has a significant and positive effect on entries by spinoff firms, whereas this is not the case in the results obtained for entries by all firms. This supports our interpretation that the local presence of haute couture designers fuelled the emergence of ready-to-wear clusters, but less so in Paris, given the significant negative sign of the Paris dummy.

${ }^{13}$ The lower entry rates in Paris may also be captured by interacting the local density of haute couture designers and the Paris dummy, a log-likelihood ratio test on the estimates of the regression models showed that the inclusion of the interaction term $\mathrm{m}^{\star}$ PARIS did not significantly improve the model fit. Thus, the relative low entry rates in Paris are a structural phenomenon as captured by the Paris dummy in Model 4, rather than a phenomenon that is specifically related to the lack of entrepreneurship from haute couture designers in the new ready-to-wear segment.

${ }^{14}$ Results are indeed consistent with the results reported in Tables 1 and 2, though more coefficients in the standard negative binomial regression results are significant compared to the zero-inflated variant. Focusing on the final model (Model $4^{\prime \prime}$ ), we note that, contrary to the results obtained with the zero-inflated variant reported in Table 2, the global legitimation effect $\left(N^{2}\right)$ is significant using the standard negative binomial regression method. Interestingly, the dummy variables controlling for the effect of the World War II in the United States and in Europe also turn out to be significant in the standard negative binomial regression, and with the expected sign for Europe.
} 
rather different from the manufacturing logic underlying the automobile industry analyzed previously. Given the rapid turnover of ideas and the role of local authorities, legitimation processes occur primarily locally, promoting further entry within the cluster. At the same time, clients for luxury fashion can be found globally, which means that firms compete both with firms in their own cluster and with firms elsewhere. By contrast, knowledge in manufacturing industries is more accumulative and codified allowing for global circulation, while manufacturing goods compete in regional markets given that transportation costs are relatively high.

Our results thus provide an explanation for the extreme and persistent geographic clustering in creative industries like fashion design. Similar creative industries like film production (Hollywood, Bollywood) and publishing (New York, London) may well exhibit the same patterns as found in this study. Such studies can attempt to verify whether the same evolutionary patterns are operating as in the fashion design industry. What is more, future studies could try to overcome some of the limits encountered in the present study, notably, the lack of additional control variables that possibly affect entry rates.

Our study also found that the growth of ready-to-wear clusters was facilitated by the presence of haute couture designers. Being a related activity, the pre-existence of a haute couture cluster provided a pool of possible entrants in the ready-to-wear segment, thus giving rise to a process of "branching" (Frenken and Boschma, 2007). However, though Paris had the largest concentration of haute couture designers, it did not succeed to dominate the new ready-to-wear segment, as it showed structurally lower entry rates than competing clusters. We attribute this failure to a form of "institutional lock-in," which frustrated the development of ready-to-wear in Paris.

\section{References}

Aldrich, H. E. and C. M. Fiol (1994), 'Fools rush in? The institutional context of industry creation,' Academy of Management Review, 19, 645-670.

Banks, M., A. Lovatt, J. O'Connor and C. Raffo (2000), 'Risk and trust in the cultural industries,' Geoforum, 31, 453-464.

Bigelow, L. S., G. R. Carroll and M. D. L. Seidel (1997), 'Legitimation, geographical scale, and organizational density: regional patterns of foundings of American Automobile Producers, 1885-1981,' Social Science Research, 26, 377-398.

Boschma, R. A. and K. Frenken (2006), 'Why is economic geography not an evolutionary science? Towards an evolutionary economic geography,' Journal of Economic Geography, 6, 273-302.

Boschma, R. A. and R. Wenting (2007), 'The spatial evolution of the British automobile industry. Does location matter?' Industrial and Corporate Change, 16, 213-238.

Breschi, S. and F. Lissoni (2009), 'Mobility of skilled workers and co-invention networks: an anatomy of localized knowledge flows,' Journal of Economic Geography, 9, 439-468. 
Buenstorf, G. and S. Klepper (2009), 'Heritage and agglomeration: the Akron tyre cluster revisited,' The Economic Journal, 119, 705-733.

Cantner, U., K. Dreßler and J. J. Krüger (2006), 'Firm survival in the German automobile industry,' Empirica, 33, 49-60.

Carroll, G. R. and M. T. Hannan (2000), The Demography of Corporations and Industries. Princeton University Press: Princeton NJ.

Cattani, G., J. M. Pennings and F. C. Wezel (2003), 'Spatial and temporal heterogeneity in founding patterns,' Organization Science, 14, 670-685.

DCMS (2001), Creative Industries Mapping Document, 2nd edn, 1st edn from 1998. Department of Culture, Media and Sports: London.

Frenken, K. and R. A. Boschma (2007), 'A theoretical framework for evolutionary economic geography: industrial dynamics and urban growth as a branching process,' Journal of Economic Geography, 7, 635-649.

Grabher, G. (1993), 'The weakness of strong ties: the lock-in of regional development in the Ruhr area,' in G. Grabher (ed.), The Embedded Firm. Routledge: London, pp. 255-277.

Hannan, M. T. and G. R. Carroll (1992), Dynamics of Organization Populations: Density, Legitimation, and Competition. Oxford University Press: New York.

Hannan, M. T. and J. Freeman (1989), Organizational Ecology. Harvard University Press: Cambridge MA.

Hannan, M. T., G. R. Carroll, E. A. Dundon and J. C. Torres (1995), 'Organizational evolution in a multinational context: entries of automobile manufacturers in Belgium, Britain, France, Germany, and Italy,' American Sociological Review, 60, 509-528.

Hassink, R. (2005), 'How to unlock regional economies from path dependency? From learning region to learning cluster,' European Planning Studies, 13, 521-535.

Jansson, J. and D. Power (2010), 'Fashioning a global city: global city brand channels in the fashion and design industries,' Regional Studies, 44, 889-904.

Klepper, S. (2002), 'The capabilities of new firms and the evolution of the U.S. automobile industry,' Industrial and Corporate Change, 11, 645-666.

Klepper, S. (2007a), 'Disagreements, spinoffs, and the evolution of Detroit as the capital of the U.S. automobile industry,' Managament Science, 53, 616-631.

Klepper, S. (2007b), 'The evolution of geographic structure in new industries,' in K. Frenken (ed.), Applied Evolutionary Economics and Economic Geography. Edward Elgar: Cheltenham, pp. 69-92.

Klepper, S. and K. L. Simons (1997), 'Technological extinctions of industrial firms; an inquiry into their nature and causes,' Industrial and Corporate Change, 6, 379-460.

Klepper, S. and P. Thompson (2006), 'Submarkets and the evolution of market structure,' RAND Journal of Economics, 37, 861-886.

Merlo, E. and F. Polese (2006), 'Turning fashion into business: the emergence of Milan as an international fashion hub,' Business History Review, 80, 415-447. 
Mezias, S. J. and J. C. Kuperman (2001), 'The community dynamics of entrepreneurship: The birth of the American film industry, 1895-1929,' Journal of Business Venturing, 16, 209-233.

O'Hara Callan, G. (1998), The Thames \& Hudson Dictionary of Fashion and Fashion Designers. Harry N. Abrams: London.

Van Wissen, L. (2004), 'A spatial interpretation of the density dependence model in industrial demography,' Small Business Economics, 22, 253-264.

Waddell, G. (2004), How Fashion Works: Couture, Ready-to-Wear and Mass Production. Blackwell Publishing: New York.

Watson, L. (2004), 20th Century Fashion: 100 Years of Style by Decade and Designer (in Association with Vogue). Firefly Books: New York.

Wenting, R. (2008), 'Spinoff dynamics and the spatial formation of the fashion design industry. 1858-2005,' Journal of Economic Geography, 8, 593-614. 


\section{Appendix A}

Table A1 Results for the zero-inflated part of the regressions

\begin{tabular}{|c|c|c|c|c|}
\hline & Model 1' & Model 2' & Model 3' & Model 4' \\
\hline$n$ & -0.572 & -0.534 & -0.519 & -0.286 \\
\hline Stand. error & $(0.229)$ & $(0.320)$ & $(0.312)$ & $(0.211)$ \\
\hline$P$-value & 0.012 & 0.096 & 0.097 & 0.174 \\
\hline$n^{2}$ & 0.006 & 0.021 & 0.020 & 0.013 \\
\hline Stand. error & $(0.002)$ & $(0.125)$ & $(0.014)$ & $(0.009)$ \\
\hline$P$-value & 0.017 & 0.150 & 0.146 & 0.154 \\
\hline$N$ & & 0.036 & 0.052 & 0.039 \\
\hline Stand. error & & $(0.085)$ & $(0.089)$ & $(0.065)$ \\
\hline$P$-value & & 0.670 & 0.557 & 0.547 \\
\hline$N^{2}$ & & -0.003 & -0.003 & -0.002 \\
\hline Stand. error & & $(0.002)$ & $(0.002)$ & $(0.002)$ \\
\hline$P$-value & & 0.202 & 0.190 & 0.186 \\
\hline$m$ & & & -0.025 & -0.122 \\
\hline Stand. Error & & & $(0.043)$ & (0.135) \\
\hline$P$-value & & & 0.552 & 0.365 \\
\hline PARIS & & & & 2.418 \\
\hline Stand. error & & & & (3.113) \\
\hline$P$-value & & & & 0.437 \\
\hline WW_US & 4.400 & 1.121 & 1.180 & 0.404 \\
\hline Stand. error & (369.115) & (3.465) & (3.611) & (3.077) \\
\hline$P$-value & 0.233 & 0.746 & 0.744 & 0.896 \\
\hline WW_EUROPE & 0.555 & 0.161 & -0.053 & 0.256 \\
\hline Stand. error & $(2.847)$ & $(3.257)$ & (3.436) & $(2.907)$ \\
\hline$P$-value & 0.845 & 0.961 & 0.988 & 0.930 \\
\hline Constant & 1.785 & 2.024 & 2.016 & 1.886 \\
\hline Stand. error & $(0.459)$ & $(0.500)$ & $(0.533)$ & $(0.602)$ \\
\hline$P$-value & 0.000 & 0.000 & 0.000 & 0.002 \\
\hline Log likelihood & -418.206 & -405.516 & -405.223 & -401.232 \\
\hline $\operatorname{LR} x^{2}$ & 45.91 & 61.65 & 61.85 & 66.04 \\
\hline Number of observations & 460 & 460 & 460 & 460 \\
\hline Number of non-zero observations & 175 & 175 & 175 & 175 \\
\hline
\end{tabular}


Table A2 Standard negative binomial regression (dependent variable: yearly founding rate in ready-to-wear)

\begin{tabular}{|c|c|c|c|c|}
\hline & Model 1" & Model 2" & Model 3" & Model 4" \\
\hline$n$ & 0.086 & 0.054 & 0.053 & 0.026 \\
\hline Stand.error & $(0.008)$ & $(0.014)$ & $(0.015)$ & $(0.016)$ \\
\hline$P$-value & 0.000 & 0.000 & 0.000 & 0.092 \\
\hline$n^{2}$ & -0.0007 & -0.0003 & -0.0003 & -0.0001 \\
\hline Stand.error & $(0.0001)$ & $(0.0001)$ & $(0.0001)$ & $(0.0001)$ \\
\hline$P$-value & 0.000 & 0.011 & 0.017 & 0.464 \\
\hline$N$ & & 0.017 & 0.017 & 0.023 \\
\hline Stand. error & & $(0.005)$ & $(0.005)$ & $(0.005)$ \\
\hline$P$-value & & 0.001 & 0.001 & 0.000 \\
\hline$N^{2}$ & & -0.00007 & -0.00007 & -0.00008 \\
\hline Stand. error & & $(0.00002)$ & $(0.00002)$ & $(0.00002)$ \\
\hline$P$-value & & 0.000 & 0.000 & 0.000 \\
\hline$m$ & & & 0.001 & 0.111 \\
\hline Stand. error & & & $(0.008)$ & $(0.026)$ \\
\hline$P$-value & & & 0.861 & 0.000 \\
\hline PARIS & & & & -2.248 \\
\hline Stand. error & & & & $(0.516)$ \\
\hline$P$-value & & & & 0.000 \\
\hline WW_US & 2.682 & 3.014 & 3.027 & 2.948 \\
\hline Stand. error & $(1.072)$ & $(1.075)$ & $(1.078)$ & $(1.077)$ \\
\hline$P$-value & 0.012 & 0.005 & 0.005 & 0.006 \\
\hline WW_EUROPE & -2.002 & -1.970 & -1.973 & -1.947 \\
\hline Stand. error & (1.013) & (1.013) & (1.014) & (1.013) \\
\hline$P$-value & 0.048 & 0.052 & 0.052 & 0.055 \\
\hline Constant & -1.718 & -1.904 & -1.915 & -2.347 \\
\hline Stand. error & $(0.149)$ & $(0.166)$ & $(0.177)$ & $(0.222)$ \\
\hline$P$-value & 0.000 & 0.000 & 0.000 & 0.000 \\
\hline Log likelihood & -437.511 & -427.886 & -427.871 & -417.780 \\
\hline $\operatorname{LR} \chi^{2}$ & 225.97 & 245.22 & 245.25 & 265.44 \\
\hline Number of observations & 460 & 460 & 460 & 460 \\
\hline
\end{tabular}

